\title{
Using "Element and Line as the Basis and the Eight Guidelines as the Body" to Construct Quality Evaluation for Ideological and Political Theory Course
}

\author{
Hongxiang $\operatorname{Sun}^{1}$ and Fei $\mathrm{Yu}^{1, *}$ \\ ${ }^{1}$ School of Marxism, Xi'an University of science and technology, Xi'an, Shaanxi 710054, China \\ *Corresponding author. Email: yufei196429@xust.edu.cn
}

\begin{abstract}
The new era puts forward unique and higher requirements for the teaching of ideological and political theory courses in Chinese universities. While the educators are adapting to these new requirements, the managers need a well-built guideline for evaluating the teaching quality of ideological and political theory courses, establishing a new course quality evaluation index system becomes essential. This paper validated the necessity of establishing a unique quality evaluation system for the ideological and political theory courses, discussed the basic thought of building it. The "element and line as the basis and the eight guidelines as the body" was brought up to better guide the evaluation system. This guideline was built with 5 first-level indicators, and there are 18 second-level indicators underneath the first-level indicators for the quality evaluation of ideological and political courses.
\end{abstract}

Keywords: ideological and political theory course, quality, evaluation index system, six requirements, eight

unifications

\section{INTRODUCTION}

At the forum of teachers of ideological and political theory in the school, the general secretary Xi Jinping stressed that the ideological and political theory course is the key course to implement the basic task of establishing moral integrity. $\mathrm{Xi}$ believed that the key to successfully running the ideological and political theory course lies in the teachers, and put forward "six requirements" and "eight unifications" [1]. This pointed out a clear direction and provided a fundamental basis for running the ideological and political theory course in colleges and universities. According to this new requirement, we must reform and innovate the teaching quality evaluation index system of the ideological and political theory courses in colleges and universities.

\section{THE NECESSITY OF ESTABLISHING A STAND-ALONE TEACHING QUALITY EVALUATION SYSTEM FOR IDEOLOGICAL AND POLITICAL THEORY COURSE}

At present, there are two main situations in the teaching quality evaluation of ideological and political theory courses in colleges and universities in China. One is to bring it into the evaluation index system in the theory course category, the other is to classify it into the same evaluation index system just like all the other courses. It is extremely rare for Chongqing Medical University to separate ideological and political courses in a special evaluation index system. There are a series of problems in China's curriculum quality evaluation, such as emphasizing commonness, ignoring individuality, single evaluation subject, and evaluation object, paying too much attention to quantitative short-term static evaluation, ignoring qualitative and long-term dynamic evaluation. The main problem is the lack of an evaluation index system for the particularity of the course. The ideological and political theory course in colleges and universities is the main channel for systematic Marxist theory education for the students. It undertakes the task of maintaining the national ideological security and cultivating socialist builders and successors, who are responsible for national rejuvenation. At present, the evaluation index system of curriculum quality in colleges and universities is not well reflecting the particularity of ideological and political theory courses.

\subsection{The Existed Curriculum Quality Evaluation Index System Cannot Well Reflect the Specific Teaching Objectives of the Ideological and Political Theory Course}

Although teaching and educating is the responsibility of teachers in various disciplines. However, due to the different nature and functional content, the meaning of "educating" is different in each discipline. The most prominent function of establishing morality and cultivating 
people in the teaching of ideological and political theory is to solve the fundamental problem of the what, how, and for whom to cultivate people. Compared with other curriculum teachers, ideological and political teachers not only spread knowledge and ideological truth but also shoulder the important task of shaping soul life. The fundamental standard to test the teaching quality of Ideological and political theory teachers is to see their educational effect, which is mainly reflected in whether students can establish a correct worldview, outlook on life and opinion on values, whether they have a firm belief in Marxism and socialism, whether they can enhance students' confidence in the theory, system and culture of socialism and China's culture, whether they can encourage students to master scientific methods and spirit, correctly treat dialectical understanding, rationally analyze practical problems, and organically combine patriotism with the ambition to strengthen and serve the country. The existing object of ideological and political theory course quality evaluation is mainly the design to evaluate teachers, which cannot well reflect the specific goal of ideological and political theory education.

\subsection{The Existed Curriculum Quality Evaluation Cannot Well Follow the Method of Ideological and Political Education}

The educational method of the ideological and political theory course is different from that of other courses. Ideological and political education must follow but later develop the rules. That is, educational activities should not only adapt to the ideological and moral status of the educatees but also surpass their current situation and reflect the requirements of social ideology and morality. Ideological and political education must follow the law of two-way interaction, and become the organic unity of the leading role of educators and the main role of educatees. Ideological and political education must follow the law of internalization and externalization, so that the educators can help and guide the students to meet the ideological and moral expectations of the society through internalization and externalization in a purposeful, planned, and organized way. Ideological and political education must follow the provisions of coordination and control. Educators should not only adhere to and coordinate the natural and conscious influence of various aspects and stages but also strive to control the influence of physique, realize the dialectical unity of conscious and spontaneous influence. Ideological and political education must follow the law of growth and development of young students and the law of the psychological acceptance of students, especially the characteristics of stability and variability, individual differences, and stages of the students. Given these laws, the evaluation system should reflect the application of regulations.

\subsection{The Existing Evaluation System is Difficult to Reflect the Requirements for the Comprehensive Quality of Ideological and Political Educators}

The teaching of the ideological and political theory involves a wide range of contents, teachers are required to have the basic theories of Marxist philosophy, political economy, science, and socialism, familiar with the latest achievements of economic and political culture, social and ecological civilization, and Party construction, be aware of the basic contents of China's reform, development, stability, internal affairs, foreign affairs, national defense, party, country, and army, and be familiar with the history of the party and the country, reform and opening up is the history of socialist development, understanding world history, international suppliers pay attention to the world situation, national conditions, party conditions, and people's conditions, etc. The universality of the teaching design content of the ideological and political theory course determines that there are high requirements for teachers' comprehensive quality. The indicators of teachers' comprehensive quality should be involved in the course evaluation.

\subsection{The Existing Curriculum Evaluation System Can't Reflect Students' Feelings of Learning and the Effectiveness of Education}

With the development and opening up and the market, new concepts and awareness affect students' thinking and behaviour. Some college students have problems such as fuzzy beliefs, distortion of value orientation, weak sense of integrity, weak social responsibility, diminished spirit of hard work, poor concept of unity and cooperation, and poor psychological quality. It is difficult for teachers to achieve practical results and achieve the teaching goals if they are blindly propagated according to the text and divorced from reality. This requires that the pertinence of teaching must be regarded as an important indicator of the quality of ideological and political courses.

\section{THE BASIC IDEA OF INNOVATING THE EVALUATION INDEX SYSTEM OF IDEOLOGICAL AND POLITICAL THEORY COURSE}

\subsection{Coupling the "Six Requirements and Eight Unifications" with the Ideological and Political Theory Teaching Quality Evaluation}

"Six requirements" is the element for the ideological and political teachers proposed by General Secretary Xi Jinping: strong politics, deep feelings, new thinking, broad 
vision, strict self-discipline, and upright personality. "Eight unifications" are based on political and academic rationality, value and knowledge, constructive and critical, theoretical and practical, unity and diversity, dominance and subjectivity, indoctrination and enlightenment, explicit education, and implicitness. The "eight unifications" are unified as the lines. Integrate these requirements into the quality evaluation indicators of ideological and political courses, and realize the coupling of the goal requirements of ideological and political courses of "six requirements as the element and eight unifications as the line" with the curriculum quality evaluation indicators. Let teachers better reflect the characteristics and target requirements of the ideological class from knowledge, affection, intention, and behavior. In this way, they can show the ideological, theoretical, pertinent characters and affinity of the ideological and political class.

\subsection{Integrating the Concept of "Eight Guidelines" into the Quality Evaluation Index}

"Eight Guidelines " refers to the diversification of evaluation subjects, the dualization of evaluation objects, the combination of static and dynamic evaluation, the equalization of quantitative and quality indicators, the unification of value orientation, the process of evaluation procedures, the motivation of evaluation functions, and the achievement of teaching goals [2].

To incorporate the concept of "eight Guidelines " into the quality evaluation indicators, the specific meanings are: (1) the diversification of evaluation subjects means that the evaluation of teachers should not only be emphasized by students but also the evaluation of students by students, including students' self-evaluation and students' evaluation of classmates; not only the evaluation of teachers by experts but also the evaluation of teachers by their peers and the evaluation of teachers themselves, valuation of the entire society. The evaluation of multiple subjects can more accurately reflect the effectiveness of teaching, (2) The dualization of evaluation objects means that the curriculum evaluation indicators should not only focus on how teachers teach, but also how students learn. The teaching process itself is a process of teaching and learning, which requires a change from the main "evaluation of teachers" to "evaluation of the classroom" while examining both aspects of teaching and learning so that both "teaching" and "learning" are emphasized, so the "learning" process should be used as an important indicator of evaluation. (3) The combination of static and dynamic evaluation is to combine the static evaluation of a certain class with the dynamic evaluation of small and scattered multiple methods and combine the short-term evaluation with the long-term evaluation. (4) Emphasizing both quantitative and qualitative indicators refer to the qualitative assessment indicators for teacher and student teaching should be organically combined with quantitative assessment indicators. This is because of the complexity and ambiguity of teaching activities, and many things are difficult to quantify, making qualitative evaluation indispensable; and because of the subjectivity and value bias of qualitative evaluation, quantitative evaluation is needed to be supplemented. (5) The unification of value orientation means that no matter which appraisal subject evaluates the teaching quality of ideological and political courses, its value orientation should be unified, which meets the overall requirements of the teaching objectives of ideological and political courses. (6) The process of the evaluation procedure is to regard evaluation as a process with both continuity and stage-wise. In the evaluation, it stresses the emotional attitude and performance of teachers and students in the process of continuity; in terms of stages, it pays attention to the learning effect of students at each stage [3]. Process evaluation is not to prove we have educated the students, but to improve teaching skills and strategies. (7) The motivating of evaluation function requires evaluators to look at and evaluate teachers' "teaching" and students" "learning" behaviors with a developmental perspective, to motivate teachers and students to develop and improve themselves, and to see if it is possible future development directions of teachers and students. (8) The achievement of teaching goals refers to the evaluation of students' learning effects, which is the core element of testing the teaching quality of ideological and political theory courses.

\subsection{Stress Students' Learning Process, Learning Feelings, and the Achievement of Teaching Objectives}

Ideological and political theory courses should educate students to establish correct belief in our road theory, system, and culture. Teachers ought to pay attention to students' learning process, thinking process, and feeling [4]. In presenting facts and reasoning, whether the educators pay attention to students' understanding and mastery of knowledge and skills, whether they stress the formation and development of students' emotions and attitudes, whether the teacher's content, language methods, and means can regulate the attention of the classroom, whether they can find the weakness for students, whether they can resonate with students, whether they are close to the students' life, if there is belief, thinking, depth, warmth, if they are ready to solve the puzzlement of students' minds, whether it can be changed like the general secretary Xi Jinping's speech "keep up with the times", are the students feel interested, comfortable to accept, active to learn and so on? These processes and feelings are directly related to whether they can moisten things silently and let the education content goes into the students' brains and hearts. Boring and pure indoctrination can only make students have rebellious psychology, and it is impossible to achieve the teaching goal of ideological and political courses. It can be seen that paying attention to students' learning process and feelings and promoting effective learning must be included in the important indicators of the quality evaluation of this kind of course [5]. 


\subsection{The Design Principles of the Evaluation Index System for the Teaching Quality of Ideological and Political Courses in the New Era}

\subsubsection{Comprehensiveness}

Comprehensiveness refers to the omnidirectional, multiangle and comprehensive teaching evaluation of Ideological and political theory courses. We should investigate the influencing factors of curriculum quality and determine the corresponding evaluation levels to form a more complete evaluation index system. (1) Examine whether the party and the state's educational policies are implemented in the general guiding ideology and meet the requirements for Ideological and political courses. (2) Examine whether teachers have comprehensive knowledge, whether if they have good teaching skills, whether they can properly guide students' learning. (3) we need to investigate whether teachers give a view of the moral education function of ideological and political teaching, whether they can cultivate students' emotional attitudes, values, and achieve certain teaching objectives, and so on.

\subsubsection{Systematicness}

Systematicness means that there must be a certain logical relationship between the indicators of Ideological and political theory teaching evaluation. They should not only reflect the main states of various subsystems such as teachers' teaching, students' learning, the effect of teacherstudent interactive learning but also reflect the internal relationship between their systems. Each subsystem is composed of a group of indicators, which are independent but also related to each other to form an organic unity. The construction of the index system is hierarchical, forming an inseparable evaluation system from the top to the bottom.

\subsubsection{Development and incentives}

Pursuing the all-around development of teachers and students is the starting point and destination of the evaluation of the ideological and political theory course. The selection of evaluation indicators should not only stress the actual performance of teachers and students but also encourage teachers and students to improve teaching and seek self-development and self-improvement.

\subsubsection{Representability and measurability}

This requires that the quality evaluation index of Ideological and political courses be qualitative, and the degree of advantages and disadvantages should be representable and can be represented by grade. When selecting quantitative indicators, specific values should also be used to upgrade and facilitate quantitative processing [6], to make the evaluation results fair and true.

\section{ESTABLISH THE QUALITY EVALUATION INDEX SYSTEM OF IDEOLOGICAL AND POLITICAL COURSE BASED ON “ELEMENTS AND LINES AS THE BASIS AND THE EIGHT GUIDELINES AS THE BODY"}

\section{1. "Elements and Lines as the Basis and the Eight Guidelines as the Body"}

"Elements and line as the basis" refers to the "six essentials" elements that the ideological and political teachers should have as the foundation, which was proposed by General Secretary Xi Jinping, and the "eight unifications" as the lines to realize the ideological and political concept of "six essentials as the element and eight unifications as the lines". Coupling of course objectives and course quality evaluation indicators. "Eight guidelines as the body" refers to the diversification of evaluation subjects, the dualization of evaluation objects, the combination of static and dynamic evaluation, the equalization of quantitative and quality indicators, the unification of value orientation, the process of evaluation procedures, the motivation of evaluation functions, and the achievement of teaching goals. These serve as the root of evaluation work, the concept of integration penetrates the evaluation index system.

\subsection{Establish a Unique Quality Evaluation Index System of Ideological and Political Theory Course}

Given the particularity of ideological and political theory courses in colleges and universities, starting from $\mathrm{Xi}$ Jinping's new requirements for ideological and political theory courses, the quality evaluation system of domestic universities and the U.S. MIT is referred. The quality evaluation of the existing ideological and political theory course has been greatly adjusted. A new evaluation index system covering 5 first-level indicators and 18 second-level indicators has been established. See Figure 1. 


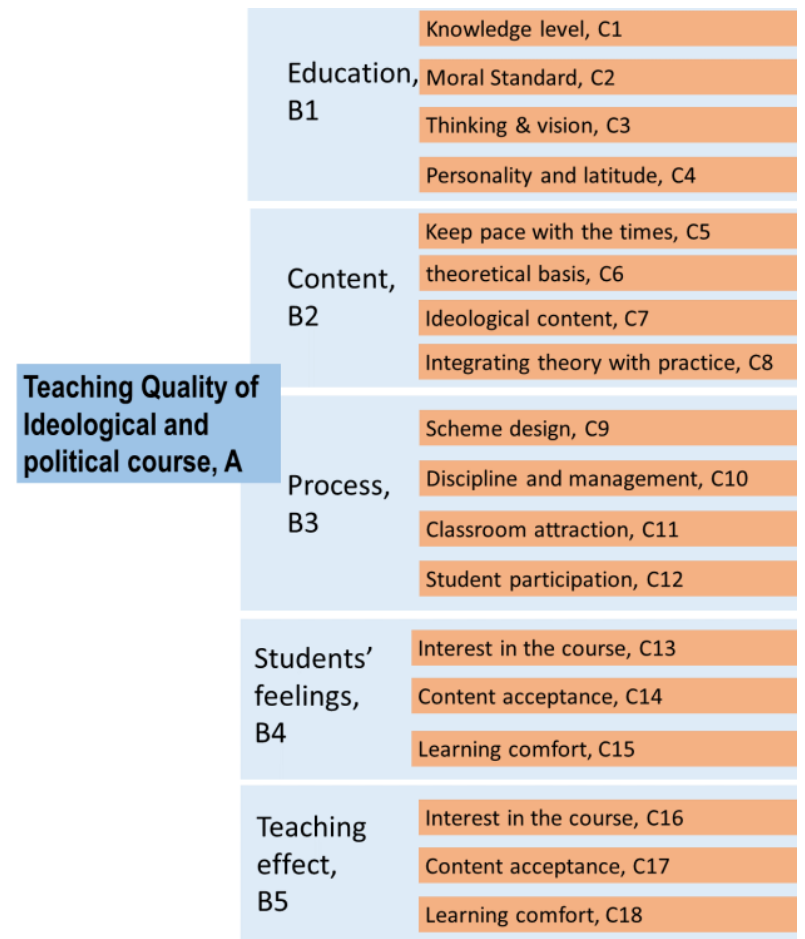

Figure 1. The strategy of the course evaluation

This indicator system not only emphasizes the commonality of all curriculum teaching, but also reflects the individuality of ideological and political theory curriculum teaching; the evaluation object emphasizes not only the evaluation of teachers' "teaching", but also the evaluation of students' "learning"; The evaluation not only pays attention the teaching process but also the teaching results.

\section{CONCLUSION}

To establish a course evaluation system that well reflects the specialized education goal and pattern of ideological and political courses, it is necessary to rethink the system from all different views. Drawing on the excellent research results and practical experience domestically and abroad, and following the principles of science and rationality, it is helpful to reconstruct the evaluation index system of ideological and political courses based on "element and line as the basis and the eight guidelines as the body".

\section{ACKNOWLEDGMENT}

Funded Project: This article is a general project in teachers' special research for the ideological and political theory courses in colleges and universities (Ministry of Education of People's Republic of China, 2020), "Research on the evaluation index system and model construction of ideological and political theory courses in colleges and universities (20JDSZK079)", "Shaanxi Provincial Social Science Fund Annual Project (2021A002)", Shaanxi Provincial Educational Reform Project: The phased results of the research and practice of the ideological and political course teaching quality evaluation system based on the requirements of the "six requirements and the eight unifications"(21BZ039).

\section{REFERENCES}

[1] Jinping Xi, Ideological and political courses are the key courses to implement the fundamental task of moral development [M]. Chinese People's Publishing House. 2019.12-16,17-23. (In Chinese)

[2] Shuming Gu, Curriculum Design and Evaluation [M]. Nanjing University Press. 2015. ISBN: 9787568114356. (In Chinese)

[3] Qiquan Zhong, From imbalance to balance: Research on the Evaluation System of Quality Education Curriculum [M]. Economic Science Press, 2014. (In Chinese)

[4] Junfeng Liu, Exploration and Analysis of the Teaching Quality Evaluation of Ideological and Political Theory Courses Based on Process. School Party Building and Ideological Education. 2018(7)24-26. (In Chinese)

[5] Yanhui Song, Research on Undergraduate Teaching Quality Improvement Strategy from the Perspective of "Student-centered" [D]. Northeast Petroleum University 2019. (In Chinese)

[6] Shuanghao She. Thoughts on the evaluation of the teaching quality of ideological and political theory courses. School Party Building and Thought 2018(7): 14-18. (In Chinese) 